\title{
Development and evaluation of a hot-melt coating technique for enteric coating
}

\author{
Arun Trambak Patil, Deepak Shamrao Khobragade*, Sandip Annaji Chafle, Amol Prasadrao \\ Ujjainkar, Sudhir Niranjanrao Umathe, Champalal Laxminarayan Lakhotia
}

Department of Pharmaceutical Sciences, Rashtrasant Tukadoji Maharaj Nagpur University, Maharashtra, India

\begin{abstract}
Conventional enteric coating requires the use of organic based polymers which are equally hazardous to the environment and operating personnel. Hot-melt coating avoids the use of solvents and is a safer and time-saving process. The present study was designed to assess the efficacy of hot-melt coating (HMC) as an enteric coating technique. Pellets prepared by extrusion spheronization were selected as the core formulation for a model of the gastric irritant drug diclofenac sodium (DFS) because of their innate advantages over single-unit formulations. Stearic acid (SA) and palmitic acid (PA) were evaluated as enteric hot-melt coating materials. HMC was carried out in a specially modified coating pan by applying SA and PA in molten state onto preheated pellets to achieve a coating level of 5-15\%w/w. Hot-melt coated pellets were evaluated for disintegration $\mathrm{pH}$ and in vitro dissolution in the $\mathrm{pH}$ range 1.2 to 6.8 , along with basic micromeritics. SEM of coated pellets showed a uniform and smooth coating. These results indicated that HMC of both SA and PA exhibited very good enteric coating ability. The coated pellets showed negligible drug release in acidic $\mathrm{pH}$. As the pellets were subsequently transferred to a higher $\mathrm{pH}$ level, a gradual increase in release of the drug from the pellets was observed with increasing $\mathrm{pH}$ of the dissolution media. The release was dependent upon coating extent, providing sustained enteric release as opposed to abrupt release with mixed release kinetics.
\end{abstract}

Uniterms: Pellets/coating/evaluation. Enteric coating/evaluation. Hot-melt coating/evaluation. Disintegration $\mathrm{pH}$. Diclofenac sodium/pellets/coating. Palmitic acid/pellets/coating. Stearic acid/pellets/ coating.

O revestimento entérico convencional requer o uso de polímeros orgânicos os quais são igualmente danosos ao meio ambiente e ao pessoal que o executa. O revestimento por fusão a quente evita o uso de solventes e é processo mais seguro e que consome menos tempo. O presente estudo foi planejado para avaliar a eficácia do revestimento por fusão a quente (RFQ) como técnica de revestimento entérico. Os péletes preparados por esferonização por extrusão foram selecionados como formulação central para modelo de fármaco irritante gástrico, o diclofenaco sódico (DFS) em razão das vantagens inerentes sobre as formulações de única dose. O ácido esteárico (AE) e o ácido palmítico (AP) foram avaliados como materiais para o revestimento de fusão a quente. O RFQ foi realizado em recipiente especialmente modificado, aplicando AS e PA no estado fundido em péletes pré-aquecidos para atingir nível de revestimento de 5 a $15 \%$ p/P. Os péletes revestidos por fusão a quente for avaliados quanto ao $\mathrm{pH}$ de desintegração e à dissolução in vitro na faixa de $\mathrm{pH}$ de 1,2 a 6,8 , juntamente com base micromerítica. $\mathrm{O}$ SEM dos péletes revestido mostrou revestimento uniforme e plano. Esses resultados indicaram que o RFQ tanto do AE quanto do AP apresentou capacidade de revestimento muito boa. Os péletes revestidos mostraram pouca liberação do fármaco em $\mathrm{pH}$ baixo. Como os péletes foram, subsequentemente, transferidos para $\mathrm{pH}$ mais altos, observou-se aumento gradual na liberação do fármaco dos péletes com o aumento do $\mathrm{pH}$ do meio de dissolução. A liberação foi dependente da extensão do revestimento, sendo a liberação entérica controlada, contrariamente à liberação abrupta com cinéticas mistas.

Unitermos: Péletes/avaliação. Pílulas/avaliaçãoentérica. Fusão a quente revestimento/avaliação. Desintegração do pH. Diclofenaco sódio/pílulas/revestimento. Palmídico ácido/pílulas/revestimento. Esteárico ácido/pílulas/revestimento.

*Correspondence: D. S. Khobragade. Department of Pharmaceutical Sciences, R.T.M. Nagpur University. Nagpur - 440 033, Maharashtra, India. E-mail: ksdeepak31@gmail.com 


\section{INTRODUCTION}

Enteric-coated dosage forms are designed to resist the acidic environment of the stomach and disintegrate in the higher $\mathrm{pH}$ environment of the intestinal fluid. The main reasons for using an enteric coating are to protect the stomach wall from the harmful effect of the drug in a dosage form (Petroski, 1989) or to prevent degradation of the drug by gastric contents (Levine et al., 1990). An enteric coating protects the drug during transit through the acidic medium of the stomach. Upon entering the higher $\mathrm{pH}$ environment of the duodenum, the coating is dissolved, and the drug becomes available for absorption. Such a coating also provides protection for the gut mucosa when the drug is capable of producing gastric distress or nausea due to irritation. Enteric coating can also be used to deliver the active ingredients that are optimally absorbed from a particular region of the intestine, e.g. to the upper part of the small intestine, so as to enhance the bioavailability of the drug.

The materials used for enteric coating are either water resistant or $\mathrm{pH}$ sensitive. Water resistant materials are digested or emulsified by intestinal juices while $\mathrm{pH}$ sensitive materials slowly swell and burst when solvated. These materials can be applied to solid dosage forms (i.e. granules, pellets, or tablets) from aqueous latex or pseudolatex, dispersions, aqueous solutions of alkali salts, or organic solvent solutions. Enteric-coated systems utilize polymeric coatings that are insoluble in the gastric media and therefore prevent or retard drug release in the stomach. Various types of ionizable polymers are commercially available. The most commonly used $\mathrm{pH}$-sensitive enteric polymers today include cellulose acetate phthalate, cellulose acetate trimellitate, hydroxypropyl methylcellulose phthalate, and methacrylic acid copolymers. These polymers dissolve at various $\mathrm{pH}$ levels ranging between 4.8 and 7.2 (Healey, 1989).

Enteric coating is generally applicable to four major types of drug, namely, those that are:

- Unstable in the gastric milieu. Examples include erythromycin, penicillin $\mathrm{V}$, pancreatin, and insulin.

- Irritants to the gastric mucosa and cause unpleasant side effects such as nausea and vomiting. Examples include aspirin and other NSAIDS (e.g. naproxen).

- Suitable candidates for delayed-release ("time controlled release") dosage forms, which provide a lag time of between 3 and $4 \mathrm{~h}$ (Healey, 1989).

- Drugs with site-specific absorption in the intestine.

The limitations of enteric-coated dosage forms include the possibility of duodenal irritation from caustic drugs and an increase in inter-subject variability due to the presentation to the small intestine of a dosage form that needs to undergo disintegration and dissolution versus a disintegrated and partially dissolved drug substance.

A common problem associated with water resistant polymer is that, to provide an enteric effect, the film might be so thick that if the dosage form travels too fast through the gastrointestinal tract, solubilization in the intestinal fluid may never be achieved. With many aqueous enteric coating formulations the risk is of premature drug release (permeation) through the enteric coat into the stomach. This can be due to increased permeability of the aqueous film coating (Heinamaki et al., 1994) or to high water solubility of the drug (Bianchini et al., 1991). If the active ingredients are freely water soluble, they may dissolve in the spray mist during the coating process, resulting in active ingredients being included in the film. Organic solvent-based systems have some disadvantages with respect to ecological, toxicological and manufacturing safety concerns. This coating has been employed for a number of drugs, including potassium chloride, ammonium chloride, aspirin, diethylstilbestrol, erythromycin, and divalproex.

A "hotmelt" is any material that undergoes a transition from a solid or semi-solid state at a lower temperature, to a liquid or semi-liquid state at a higher temperature (Lorenzi et al., 2001). Receiving much attention recently, hot-melt coating systems have become an immerging area in the pharmaceutical industry and concerted effort has been made to develop alternatives to organic and aqueous polymer systems (Achanta et. al., 1997). There are various hot-melt coating techniques, including melt coating, hotmelt spray coating, solid dispersion hot-melt coating, and hot-melt direct blending coating, melt granulation, melt extrusion, melt dispersion and pastillation (Gokonda et al., 1994; Kim et al., 2003; Nadia et al., 2002). Development of novel lipophilic excipients has provided impetus to research in the area of processing techniques involving molten states (Sinchaipanid et al., 2004). Hot-melt coatings have various advantages over coatings with polymer solutions or dispersions. The coating material can be applied without organic solvents, at a high application rate. Therefore shorter processing time is required for hot-melt coating. These coatings can be applied onto solid dosage forms in the form of hot melts, hot emulsions or suspensions (colloidal particles). In basic hot-melt coating, the coating material is applied onto the substrate surface in the hot-melt state.

The objective of this study was to evaluate effectiveness of hot-melt coating technique as a method to obtain enteric coating. Multiple-unit dosage form pellets were selected because they are equally distributed throughout the gastrointestinal tract and the gastrointestinal transit 
time of such systems are more reproducible and repeatable than those of single-unit tablets or capsules (Davis et al., 1984; Hardy et al., 1985).

Diclofenac sodium (DFS) was selected as the model drug because it has a tendency for causing gastric irritation and even ulceration in some cases and is an ideal drug candidate for enteric coating. Stearic acid (SA) and Palmitic acid (PA) were selected as the hot-melt enteric coating materials.

\section{MATERIAL AND METHODS}

\section{Material}

Diclofenac sodium was received as a gift sample from Zim laboratories Ltd., Nagpur, India. Stearic acid and Palmitic acid were purchased from S.D. Fine Chemicals, India. Microcrystalline cellulose (Avicel PH 101), Lactose monohydrate and Povidone (Kollidon 30) were generously gifted by FMC biopolymer (Mumbai, India), S. D. Fine Chemicals (Mumbai, India) and BASF India Ltd. (Mumbai, India), respectively. All other reagents were of analytical grade and used as received.

\section{Methods}

\section{Preparation of pellets}

The composition of various batches is given in Table I. Pellets of DFS with microcrystalline cellulose (MCC Avicel PH 101) - lactose monohydrate were prepared by extrusion spheronization using Povidone (Kollidon 30) as a binder and water as the granulating fluid. A damp mass was prepared by mixing DFS, MCC, lactose and granulating this with binder solution. The damp mass was then extruded through a die-roller extruder (EXT65/10-2000, Umang Pharmatech, India). Extrudes were spheronized using a spheronizer (SPH-150/05, Umang Pharmatech, India) with a $1.2 \mathrm{~mm}$ cross hatch plate at $900 \mathrm{rpm}$ for 5 minutes. The pellets were dried at $60{ }^{\circ} \mathrm{C}$ for 2 hours in a hot air oven (SMC-120, Spectrum Pvt. Ltd., Mumbai).

\section{Hot-melt coating of pellets}

A modified coating spray gun was fabricated for the hot-melt coating. The gun consisted of three parts viz. spraying assembly, air handling system and coating chamber. The spraying system consisted of a spray gun with an air atomization nozzle attached to the feed input port. The nozzle was a pneumatic type two fluid nozzle with a needle valve for regulating flow rate of coating material. A feed input port provides coating material,
TABLE I - Formulations of SA and PA coated pellets. All quantities indicated in \%w/w basis. DFS- Diclofenac sodium, SA- Stearic acid, PA- Palmitic acid

\begin{tabular}{lcccccc}
\hline \multirow{2}{*}{ Ingredients } & \multicolumn{6}{c}{ Formulations } \\
\cline { 2 - 7 } & F1 & F2 & F3 & F4 & F5 & F6 \\
\hline Pellet Composition & & & & & & \\
DFS & 20 & 20 & 20 & 20 & 20 & 20 \\
MCC & 47 & 47 & 47 & 47 & 47 & 47 \\
Lactose & 30 & 30 & 30 & 30 & 30 & 30 \\
PVP & 3 & 3 & 3 & 3 & 3 & 3 \\
\hline Coating Composition & & & & & & \\
SA $^{\#}$ & 5 & 10 & 15 & - & - & - \\
PA $^{\#}$ & - & - & - & 5 & 10 & 15 \\
\hline
\end{tabular}

maintained at a specific temperature with a mini immersion heater, to the nozzle from a feed reservoir mounted on it. An air input port from an air handling system was also attached to this junction. The diameter of the feed output port was $1 \mathrm{~mm}$ and that of air output port was 2.5 $\mathrm{mm}$. The air handling system consisted of an air heating unit and air compressor. The air heating assembly comprised a 2.5 - $\mathrm{ft}$ long steel pipe with an inner diameter of 1.5 inch. A 1000 watt heating coil insulated with borosilicate glass pipe placed between coil and metal pipe was inserted into the steel pipe. Current supply to the coil was provided through $\mathrm{T}$ joints at the ends of the metal pipe through a thermostat. The steel pipe was insulated with an insulating glass wool jacket. An air pressure compressor $(0.5 \mathrm{HP})$ with a 3.37 CFM displacement capacity was attached to the steel pipe to provide actuating air pressure. Compressed air was passed through the heating unit and fed into the nozzle through the air input port. The coating chamber was a pear-shaped stainless steel coating pan 4 inches in diameter with 4 tubular baffles and a maximum capacity of 0.5 liters. It was attached to the shaft of a single drive motor with a rotation speed of $35 \mathrm{rpm}$ and can be dismantled for cleaning.

Two waxes were selected for the hot-melt coating (HMC), namely, SA and PA. The waxes were melted in separate containers. Pre-weighed drug-containing pellets were placed into the hot-melt coating pan and allowed to attain a temperature of about $50{ }^{\circ} \mathrm{C}$. The molten wax was sprayed over tumbling pellets in small installments with constant rotation of the pan. After each addition, the pan was allowed to rotate for a further period of around 5 minutes and then the next installment of wax was added. The coating level was determined by frequently taking weight readings of the coated pellets until the desired coating level was achieved. 


\section{Evaluation of hot-melt coated pellets}

The hot-melt coated sustained release pellets were evaluated for the following parameters.

- Size Distribution (Fekete et al., 1998):

The size distribution was determined using a sieve shaker and set of 4 ASTM sieves (\# 10, \#14, \#20, and \#30) for 5 minutes. The size distribution expresses the efficiency of the process to manufacture uniform-sized pellets. Mean pellet size was calculated according to the following equation.

$$
d \text { avg }=\sum \frac{\% \text { retained X Avg. sieve aperture }}{100}
$$

- Crushing strength and friability of the pellets (Gandhi et al., 1990):

The crushing strength of hot-melt coated pellets was examined by a Veego digital dial type hardness tester (Veego Scientific, India).

For the friability study, a $1.0 \mathrm{~g}$ pre-weighed sample, collected on a sieve having $0.85 \mathrm{~mm}$ apertures with 25 glass beads ( $3 \mathrm{~mm}$ in diameter) were placed in a Roche friabilator (Veego India Ltd.) and operated for 100 revolutions at a speed of $25 \mathrm{rpm}$. The mass of pellets was collected again on a sieve with $0.85 \mathrm{~mm}$ apertures. The smaller particles were allowed to pass through the sieve and pellets reweighed. Friability was determined as the percentage loss of mass of the pellets post test.

- Determination of bulk and tapped density:

For measuring bulk density, $25 \mathrm{~g}$ of pellets of 14/20 mesh fraction were poured gently through a glass funnel into a $100 \mathrm{ml}$ calibrated measuring cylinder. The surface was carefully made smooth. The density was then calculated by dividing weight by volume.

The tapped density was also measured in a similar fashion as bulk density but the final volume was measured after the cylinder was tapped from the height of 3 inches until a constant volume was obtained. Compressibility index and Hausner ratio were determined from bulk density and tapped density values.

- Determination of drug content:

The drug content was determined by weighing crushed sample equivalent to $50.0 \mathrm{mg}$ of Diclofenac sodium. The sample was diluted with $6.8 \mathrm{pH}$ phosphate buffer and sonicated for 20 minutes (3.5L 100, PCi, Mumbai, India), centrifuged and filtered through $1 \mu \mathrm{m}$ finer porosity filter. A $5.0 \mathrm{~mL}$ volume of this solution was taken, the sample diluted suitably and absorbance measured at
$276.0 \mathrm{~nm}$ using a UV spectrometer (Shimadzu-UV-150-02 Kyoto, Japan).

- Scanning electron microscopy:

The coated pellets were sputtered with gold for 5 min using a sputter coater (Auto Fine Coater, JFC-1300, Jeol, Tokyo, Japan). The surface was examined by scanning electron microscopy (SEM, Jeol JSM 5600 LV, Jeol, Tokyo, Japan) at $10 \mathrm{kV}$.

- Determination of disintegration pH of pellets (Marvola et al., 1999).

Release rate of the DFS from uncoated and coated pellets was studied as a function of gradual increase in $\mathrm{pH}$ of the dissolution medium (Marvola et al., 1989). The test was carried out on a USP XXIV type I dissolution test apparatus. Initially, the pellets were placed in a basket. A $500 \mathrm{~mL}$ volume of $0.1 \mathrm{M} \mathrm{HCl}(\mathrm{pH} 1.2)$ was taken as the dissolution medium and stirred at $50 \mathrm{rpm}$. After an initial period of $15 \mathrm{~min}$, the $\mathrm{pH}$ was gradually increased every tenth minute by addition of $0.4 \mathrm{M}$ disodium hydrogen phosphate. Drug concentrations prior to each addition of Disodium hydrogen phosphate were measured spectrophotometrically after alkalization by $1 \mathrm{~N} \mathrm{NaOH}$ at $276 \mathrm{~nm}$. Maximum dissolution rate of the model drug was considered indicative of the $\mathrm{pH}$ value at which pellet disintegration had occurred. This test provides some notion of the suitability of these materials as enteric coating materials.

\section{Drug release study}

In vitro drug release from hot-melt enteric coated pellets was assessed using dissolution a testing apparatus USP XXIV type I (Veego Scientific India, Ltd.) at $100 \mathrm{rpm}$ in $900 \mathrm{~mL}$ of $0.1 \mathrm{~N} \mathrm{HCl}$ for the first 2 hours followed by pH 6.8 Phosphate buffer. The percentage drug released from the pellets was determined using UV-spectroscopy with reference to a linear calibration curve at a wavelength of $276 \mathrm{~nm}$. The dissolution data was computed in light of different kinetic equations (Costa et al., 2001) to help clarify the release mechanism of the drug from the hotmelt enteric coated pellets.

\section{RESULTS AND DISCUSSION}

\section{Evaluation of hot-melt enteric coated pellets}

The results of the evaluation of pellets are summarized in Table II. All the batches prepared by extrusion spheronization showed very good micromeritic properties. The application of the hot-melt coating of SA and PA resulted in further improvement of these properties. 
PA formed a comparatively smoother and elegant pellet coat than SA. The pellets had very good uniformity as desired and all formulations were within the size range of 800 to $1000 \mu$ after hot-melt coating and exhibited a shape approaching that of a sphere. Values of angle of repose were approximately $18-25^{\circ}$ for all formulations. The surface was very smooth and particle size distribution was narrow. All these factors yielded very good flowability. Friability was negligible, having a maximum value of $0.2 \%$. This value can be attributed to the loosening of some wax from the coating due to attrition of the friability test. Pellet hardness, measured with a dial type hardness tester (Veego India Ltd.), was around $1.5 \mathrm{~kg} / \mathrm{cm}^{2}$. Both these values indicated that the pellets had good mechanical strength.

\section{Scanning electron microscopy (SEM)}

Figures 1-6 show microphotograph and scanning electron micrographs of hot-melt enteric coated pellets.

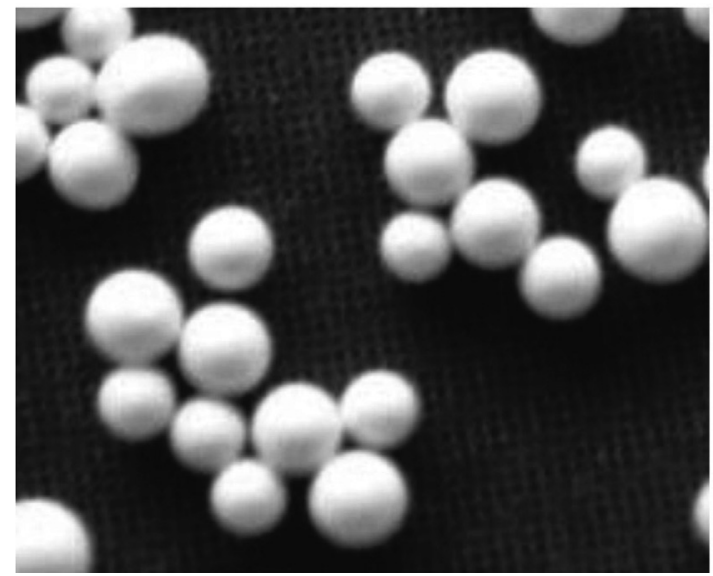

FIGURE 1 - Photograph of stearic acid coated pellets.

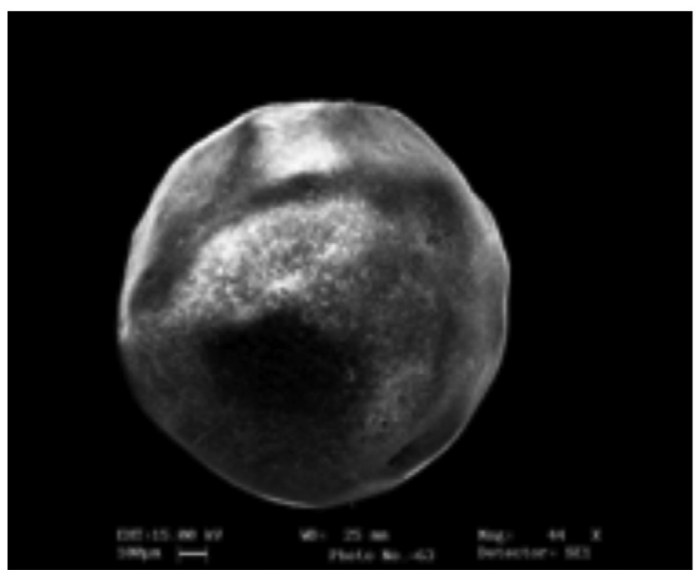

FIGURE 2 - Scanning electron micrograph of stearic acid coated pellets (30X).
Scanning electron microscopy was performed to study surface morphology. The scanning electron micrographs show a smooth surface and uniform coating. Pellets also exhibited a spherical shape.

\section{Determination of disintegration $\mathrm{pH}$}

The disintegration $\mathrm{pH}$ was considered the $\mathrm{pH}$ at which coated pellets showed the highest amount of drug release at minimum fixed time. The material must be solubilized at alkaline $\mathrm{pH}$ to be considered suitable for enteric coating. Only results of $5 \%$ wax coated pellets were shown for this test as the time period for the test was very short and not adequate for release from pellets with higher percent coatings i.e. $10 \%$ and $15 \%$. Due to lower extent of coating, an amount of the drug was also found to be released at acidic $\mathrm{pH}$. This might have been due to coating erosion and not solubilization as the core pellets were intact even after completion of the test. The drug release gradually increased with greater $\mathrm{pH}$ levels as can be seen

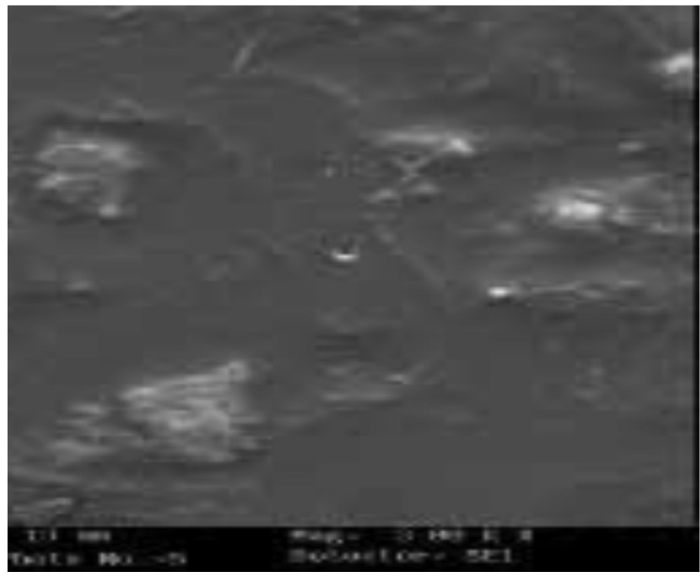

FIGURE 3 - Scanning electron micrograph of stearic acid coated pellets (500X).

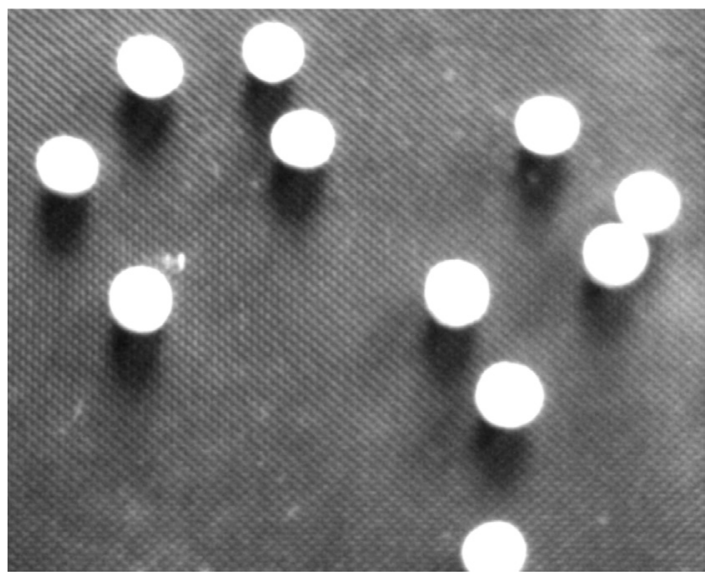

FIGURE 4 - Photograph of palmitic acid coated pellets. 


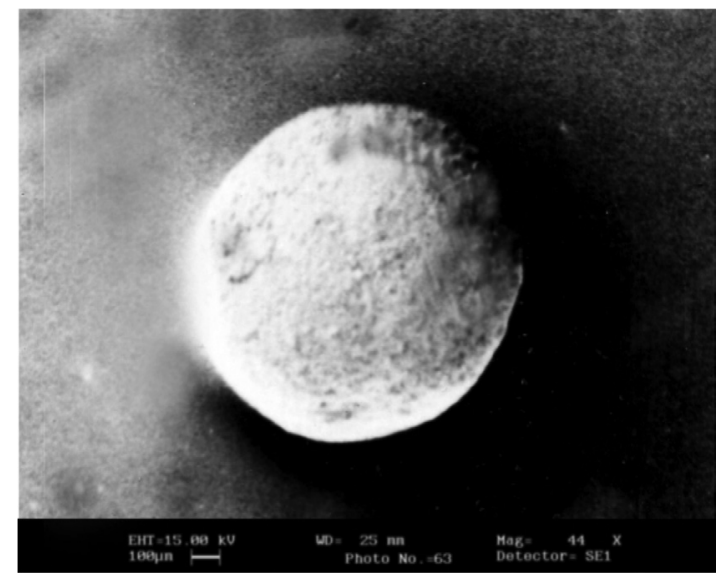

FIGURE 5 - Scanning electron micrograph of palmitic acid coated pellets (30X).

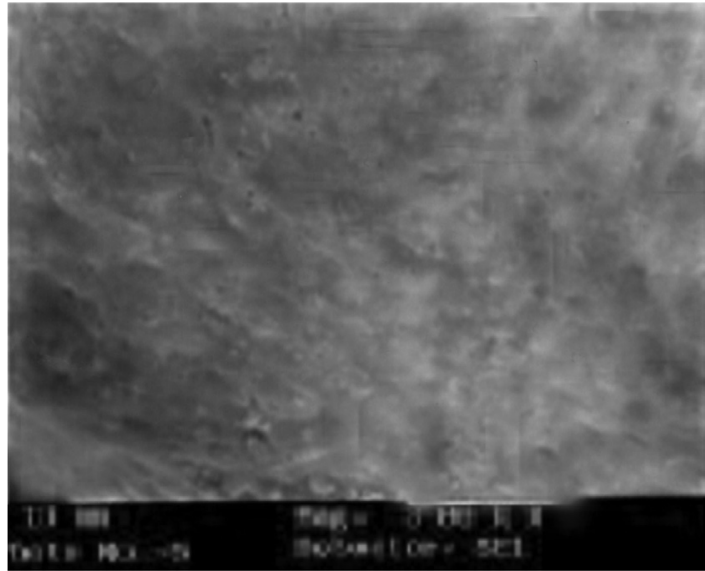

FIGURE 6 - Scanning electron micrograph of stearic acid coated pellets (500X).

TABLE II - Evaluation of uncoated and hot-melt enteric coated pellets

\begin{tabular}{lcccccccc}
\hline Formulations & \% Friability & $\begin{array}{c}\text { Hardness } \\
\left(\mathrm{kg} / \mathrm{cm}^{2}\right)\end{array}$ & $\begin{array}{c}\text { Angle of } \\
\text { repose }(\theta)\end{array}$ & $\begin{array}{c}\text { Bulk density } \\
\left(\mathrm{g} / \mathrm{cm}^{3}\right)\end{array}$ & $\begin{array}{c}\text { Tap density } \\
\left(\mathrm{g} / \mathrm{cm}^{3}\right)\end{array}$ & $\begin{array}{c}\text { Hausner } \\
\text { Ratio }\end{array}$ & $\begin{array}{c}\text { Carr's } \\
\text { Index }\end{array}$ & $\begin{array}{c}\text { Mean particle } \\
\text { diameter }(\mu)\end{array}$ \\
\hline F1 & 0.1 & 1.4 & 22.22 & 0.82 & 0.93 & 1.13 & 2.79 & 890 \\
F2 & 0.0 & 1.5 & 20.86 & 0.82 & 0.93 & 1.13 & 11.58 & 899 \\
F3 & 0.2 & 1.6 & 19.66 & 0.82 & 0.93 & 1.12 & 10.42 & 918 \\
F4 & 0.1 & 1.4 & 21.97 & 0.82 & 0.92 & 1.12 & 10.48 & 864 \\
F5 & 0.0 & 1.6 & 20.13 & 0.80 & 0.91 & 1.13 & 11.54 & 877 \\
F6 & 0.1 & 1.6 & 18.98 & 0.87 & 0.89 & 1.03 & 11.33 & 894 \\
Uncoated & 0.2 & 1.3 & 25.33 & 0.78 & 0.88 & 1.13 & 10.23 & 840 \\
\hline
\end{tabular}

in the graph. Contrary to previous studies (Marvola et al., 1999) however, the drug release, although increased, was not abrupt but instead showed a slow and steady rise in release. This indicated that the PA and SA resist the gastric environment and will not release drug suddenly but gradually in the intestinal environment.

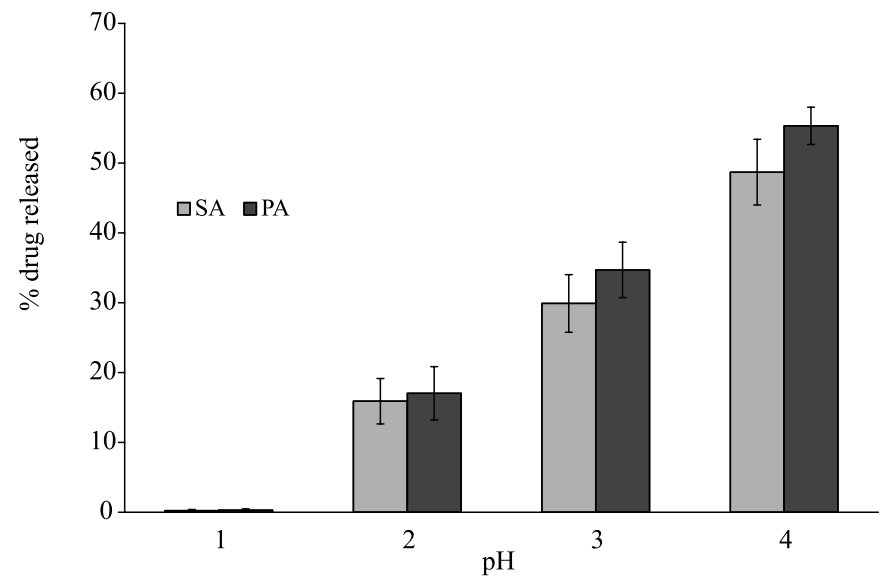

FIGURE 7 - Disintegration $\mathrm{pH}$ of $5 \% \mathrm{w} / \mathrm{w}$ enteric coated pellets as determined by drug release (mean $\pm \mathrm{SD}, n=3$ ).

\section{In vitro dissolution}

The dissolution study was carried out to determine the resistance of the materials viz. SA and PA to the acidic environment of the stomach and their suitability as enteric coating materials. Ideally for enteric coating, there should be no release of drug in the acidic $\mathrm{pH}$ of the stomach, where this was determined in vitro by carrying out dissolution at $0.1 \mathrm{~N}$ $\mathrm{HCl}$ for the first two hours. Dissolution was subsequently continued in 6.8 phosphate buffer. The drug release data of the dissolution study is shown graphically in Figure 8 . The gastric residence time of non-disintegrating pellets (diameter 1-2 $\mathrm{mm}$ ) under fasting conditions has been shown to be from 0.4 to $2 \mathrm{~h}$, with a mean of $1.2 \mathrm{~h}$ (Hardy et al., 1985; Marvola et al., 1989). Intestinal transit times for different dosage forms, independently of diameter, are $2-4 \mathrm{~h}$ with a mean of $3 \mathrm{~h}$ (Clarke et al., 1993; Coupe et al., 1991). It can therefore be calculated that most of a pellet formulation should be at the end of the small intestine $4 \mathrm{~h}$ after drug administration (Marvola et al., 1999).

The graph indicates that both SA and PA exhibited very good enteric coating ability. Some drug was released 
TABLE III - Correlation coefficients (r) for Hot-Melt Enteric coated Diclofenac sodium pellets

\begin{tabular}{lccccc}
\hline Formulations & Zero order & 1st order & Matrix & Peppas & Hixson-Crowell \\
\hline F1 & 0.8650 & 0.8645 & 0.7195 & 0.9381 & 0.8646 \\
F2 & 0.9670 & - & 0.9821 & 0.9714 & 0.8044 \\
F3 & 0.9999 & 0.9998 & 0.9574 & 1.0000 & 0.9998 \\
F4 & 1.0000 & 0.9999 & 0.9792 & 1.0000 & 1.0000 \\
F5 & 0.9027 & 0.9023 & 0.7634 & - & 0.9025 \\
F6 & 0.9387 & - & 0.8196 & - & 0.8452 \\
\hline
\end{tabular}

in acidic $\mathrm{pH}$ at the lower coating level of $5 \%$, whereas at a higher coating level there was practically zero drug release from the pellets. As the pellets were transferred to the higher $\mathrm{pH}$ level of 6.8 , there was an abrupt increase in release of the drug from the pellets. This release was dependent upon coating extent. Significant differences were noted in the drug release pattern of the pellets containing 5 and $15 \%$ wax coat. This suggests it is possible to retard drug release or extend lag time in relation to commencement of drug absorption by making the coat thicker at $15 \%$ rather than $5 \%$. This is contrary to the findings with conventional enteric polymers (Aqoat AS-HF) as this polymer shows no significant effect of coatings above a $20 \%$ level (Marvola et al., 1999). This might be due to the inherent property of materials evaluated and their solubility mechanism. SA and PA first undergo saponification at higher $\mathrm{pH}$ and then become dissolved; it takes longer to dissolve the coat and increase drug release.

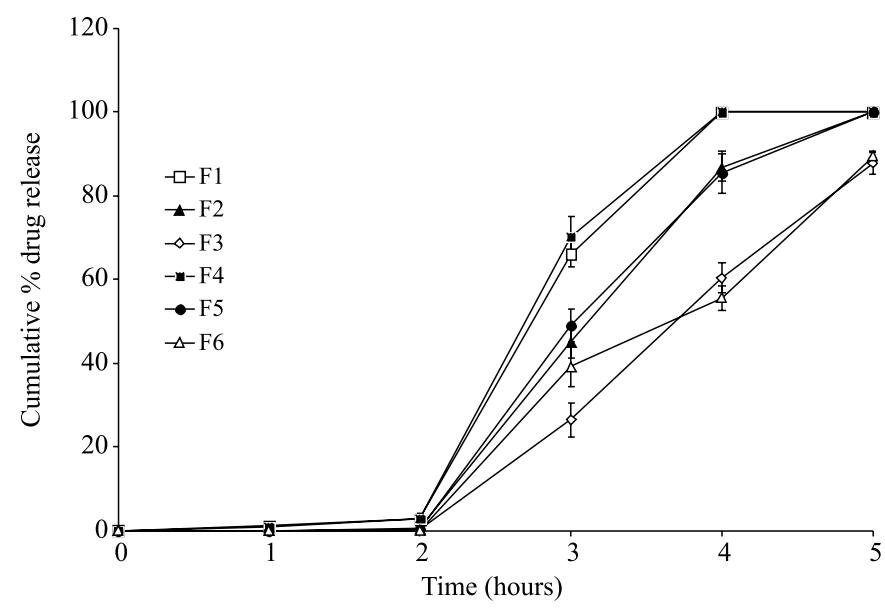

FIGURE 8 - Dissolution study of enteric coated pellets. (mean $\pm \mathrm{SD}, n=3$ ).

\section{Release kinetics}

The values for correlation coefficients according to the different kinetic equations are given in Table III. A release kinetics study according to goodness of fit shows that DFS followed the Peppas model (For Batch F1 to F4) for both waxes, indicating drug release by diffusion and erosion. The batch F5 and F6 showed release by zero order. The close proximity of correlation coefficients indicated that no single mechanism was completely dominant and confirmed that release was governed by more than one mechanism.

\section{CONCLUSION}

Both the studied hot-melt coating agents (PA and SA) were found to have good enteric coating ability. At a low wax coating level $(5 \% \mathrm{w} / \mathrm{w})$ negligible amounts of drug were released in the acidic environment after 2 hours. At and above a $10 \%$ coating, practically zero drug release was observed in acidic $\mathrm{pH}$. A slower rate of drug release was observed with increased coating level.

The results of the present study showed that hot-melt coating materials can constitute an excellent alternative to conventional enteric polymers. The hot-melt coating technique can be an efficient, eco-friendly and economical tool for formulating enteric coated pellets.

\section{ACKNOWLEDGEMENT}

The authors would like to thank M/s. Zim Laboratories Ltd., Nagpur, India for the gift sample of the active drug.

\section{REFERENCES}

BIANCHINI, R.; RESCINITI, M.; VECCHIO, C. Technology evaluation of aqueous enteric coating systems with and without insoluble additives. Drug Dev. Ind. Pharm., v.17, p.1779-1794, 1991.

BIFODAN, A.S. Enteric coating, comprising alginic acid, for an oral preparation. Eur. Pat. 0952824, 29 September 2004. 
CHAMBLISS, W.G. Enteric coatings. In: SWARBRICK, J.; BOYLAN, J.C. (Eds.). Encyclopedia of pharmaceutical technology. New York: Marcel Dekker, 1992. p.189-200.

CLARKE, G.; NEWTON, J.; SHORT, M. Gastrointestinal transit of pellets of differing size and density. Int. J. Pharm., v.100, p.81-92, 1993.

COSTA, P.; LOBO, L.M.S. Modeling and comparison of dissolution profiles. Eur. J. Pharm. Sci., v.13, p.123-133, 2001 .

COUPE, A.; DAVIS, S.; WILDING, I. Variation in gastrointestinal transit of pharmaceutical dosage forms in healthy subjects. Pharm. Res., v.8, p.360-364, 1991.

DAVIS, S.; HARDY, J.; TAYLOR, M.; WHALLEY, D.; WILSON, C. A comparative study of gastrointestinal transit of a pellet and tablet formulation. Int. J. Pharm., v.21, p.167-177, 1984.

FEKETE, R.; ZELKO, R.; MARTON, S.; RACZ, I. Effect of the formulation parameters on the characteristics of pellets. Drug Dev. Ind. Pharm., v.24, p.1073-1076, 1998.

GOKONDA, S.R.; HILEMAN, G.A.; UPADRASTHA, S.M. Development of matrix controlled release beads by extrusion-spheronization techniques technology using a statistical screening design. Drug Dev. Ind. Pharm., v.20, p. 279-292, 1994.

HARDY, J.; WILSON, C.; WOOD, E. Drug delivery to the proximal colon. J. Pharm. Pharmacol., v.37, p.874-877, 1985.

HASEGAWA, A.; KAWAMURA, R.; NAKAGAWA, H.; SUGIMOTO, I. Physical properties of solid dispersions of poorly water-soluble drugs with enteric coating agents. Chem. Pharm. Bull., v.33, p.3429-3435, 1985.

HASEGAWA, A.; NAKAGAWA, H.; SUGIMOTO, I. Application of solid dispersions of nifedipine with enteric coating agent to prepare a sustained-release dosage form. Chem. Pharm. Bull., v.33, p.1615-1619, 1985.

HEALEY, J.N.C. Enteric coatings and delayed release. In: HARDY, J.G.; DAVIS, S.S.; WILSON, C.G. (Eds.). Drug delivery to the gastrointestinal tract. Chichester: Ellis Horwood, 1989. p.83-96.
HEINAMAKI, J.T.; COLARTE, A.I.; NORDSTROM, A.J.; YLIRUUSI, J.K. Comparative evaluation of ammoniated aqueous and organic-solvent-based cellulose ester enteric coating systems: a study on free films. Int. J. Pharm., v.109, p.9-16, 1994.

KANAZAWA, H.; SHIMIZU, K.; SASAKI, K.; SUGIMOTO, T. Bubbling enteric coated preparations. US Pat. 6326360 , 25 September 2000.

KIM, J.W.; ULRICH, J. Prediction of degree of deformation and crystallization time of molten droplets in pastillation process. Int. J. Pharm., v.257, p.205-215, 2003.

LAMPARD, J. Bimodal release of ibuprofen in a sustainedrelease integrating solid formulations in humans. Int. J. Pharm., v.60, p.89-97, 1989.

LEE, Y.; KIM, S.H.; BYUN, Y. Oral delivery of new heparin derivatives in rats. Pharm. Res., v.17, p.1259-1264, 2000.

LEVINE, M.M.; FERRECCIO, C.; CRYZ, S.; ORTIZ, E. Comparison of enteric-coated capsules and liquid formulation of Ty 21 a typhoid vaccine in randomised controlled field trial. Lancet, v.336, p.891-894, 1990.

LORENZI, M.P.; SMITH, E.D.; PHIPPS, N.J. Personal care articles comprising hotmelt compositions. US Pat. 20010018068, 30 August 2001.

MARVOLA, M.; KANNIKOSKI, A.; AITO, H.; NYKANEN, $\mathrm{S}$. The effect of food on gastrointestinal transit and drug absorption of a multiparticular sustained-release verapamil formulation. Int. J. Pharm., v.53, p.145-155, 1989.

MARVOLA, M.; NYKANEN, P.; RAUTIO, S.; ISONEN, N.; AUTERE, A.M. Enteric polymers as binders and coating materials in multiple-unit site specific drug delivery systems. Eur. J. Pharm. Sci., v.7, p.259-267, 1999.

NADIA, P.; BEATRICE, A.; CRISTINA, C.; LORENZO, R. Preparation and characterization of ibuprofen-poloxamer 188 granules obtained by melt granulation. Eur. J. Pharm. Sci., v.15, p.71-78, 2002.

NISHIMURA, K.; SASAHARA, K.; ARAI, M.; NITANAI, T.; IKEGAMI, Y.; MORIOKA, T.; NAKAJIMA, E. Dosage form design for improvement of bioavailability of levodopa VI: formulation of effervescent enteric-coated tablets. $J$. Pharm. Sci., v.73, p.942-946, 1984. 
PETROSKI, D. Endoscopic comparison of various aspirin preparations: gastric mucosal adaptability to aspirin restudied. Curr. Ther. Res. Clin. Exp., v.45, p.945-954, 1989.
SINCHAIPANID, N.; JUNYAPRASERT, V.; MITREVEJ A. Application of hot-melt coating for controlled release of propranolol hydrochloride pellets. Powder Tech., v.141, p.203-209, 2004.

Received for publication on $15^{\text {th }}$ Mach 2011 Accepted for publication on $20^{\text {th }}$ September 2011 